\title{
Severe reaction to radiotherapy for breast cancer as the presenting feature of ataxia telangiectasia
}

\section{PJ Byrd', V Srinivasan', JI Last', A Smith', P Biggs', EF Carney', A Exley², C Abson ${ }^{3}$, GS Stewart', L Izatt ${ }^{4}$ and AM Taylor,}

'School of Cancer Sciences, College of Medical and Dental Sciences, University of Birmingham, Vincent Drive, Edgbaston, Birmingham BI 5 2TT, UK; ${ }^{2}$ Immunology Laboratory, Department of Pathology, Papworth Hospital NHS Foundation Trust, Cambridge University Health Partners, Cambridge CB23 3RE, UK: ${ }^{3}$ Kent Oncology Centre, Maidstone Hospital, Hermitage Lane, Maidstone, Kent ME 16 9QQ, UK; ${ }^{4}$ Clinical Genetics Department, Guy's and St Thomas's NHS Foundation Trust, 7th Floor Borough Wing, Great Maze Pond, London SEI 9RT, UK

BACKGROUND: Severe early and late radiation reaction to radiotherapy is extremely rare in breast cancer patients. Such a reaction prompted an investigation into a 44-year-old mother (patient A-T2 I3).

METHODS: A neurological examination was performed and blood lymphocytes and skin fibroblasts were assessed for radiosensitivity chromosomally and by colony-forming assay. The ATM gene was sequenced and ATM mutations modelled by site-directed mutagenesis. The ATM kinase activity was also assessed.

RESULTS: Patient A-T2I3 was normally ambulant with no ataxia and minimal other neurological features. T lymphocytes and skin fibroblasts were unusually radiosensitive, although less sensitive than in classical ataxia telangiectasia (A-T). A lymphoblastoid cell line and skin fibroblasts expressed ATM protein with some retained kinase activity. One missense ATM mutation c.8672G $>$ A (p.Gly289|Asp) and a c.|A>G substitution were identified. In the modelling system the p.Gly289|Asp mutant protein was expressed and shown to have residual ATM kinase activity.

CONCLUSION: Patient A-T2I3 has a milder form of A-T with biallelic ATM mutations, which may have contributed to breast cancer development, and certainly caused the severe radiation reaction. Ataxia telangiectasia should be investigated as a potential cause of untoward severe early and late radiation reactions in breast cancer patients.

British Journal of Cancer (2012) I 06, 262-268. doi:I0.1038/bjc.20II.534 www.bjcancer.com

Published online 6 December 2011

(c) 2012 Cancer Research UK

Keywords: ATM; ataxia telangiectasia; breast cancer; radiosensitivity; radiotherapy

Classical ataxia telangiectasia (A-T) is an early-onset progressive neurodegenerative disorder caused by loss of function of the ATM gene. Affected individuals are unable to walk a few steps independently by early adulthood. This phenotype is most frequently caused by biallelic null mutations in ATM that result in the absence of ATM, a large $370 \mathrm{kDa}$ protein kinase (Taylor and Byrd, 2005). ATM phosphorylates many target proteins such as H2AX, MDC1, 53BP1, Nbs1, BRCA1, Chk2 and p53 that function to regulate DNA DSB repair, chromatin remodelling, cell cycle checkpoint activation, gene transcription, protein translation and apoptosis (Lavin, 2008). In A-T, in the absence of ATM there is a defective response to both intrinsically and extrinsically derived cellular damage. In the brain, damaged cells may become incorporated into neuronal tissues, leading to neurodegeneration, possibly as a result of failure of apoptosis (Shull et al, 2009).

Clinically, A-T is quite heterogeneous with some nonclassical patients showing a much milder clinical progress as a consequence of retaining expression of either some normal (McConville et al, 1996; Sutton et al, 2004) or mutant ATM protein (Stankovic et al, 1998; Carrillo et al, 2009; Verhagen et al, 2009) with residual ATM

*Correspondence: Dr AM Taylor; E-mail: A.M.R.Taylor@bham.ac.uk Received 7 September 2011; revised 25 October 2011; accepted 8 November 20 I ; published online 6 December 20I I kinase activity. Indeed, some A-T patients are not diagnosed until adulthood (Sutton et al, 2004; Hiel et al, 2006).

Separate studies of A-T families (Olsen et al, 2001; Thompson et al, 2005b) and of breast cancer families (Renwick et al, 2006) have shown that carrying a single ATM mutation doubles the risk of breast cancer. The presence of the missense mutation, c.7271T $>$ G (p.Val2424Gly), further increases the risk (Stankovic et al, 1998; Bernstein et al, 2006). Also, A-T patients are at a considerable increased risk of developing breast cancer; $45 \%$ by the age of 50 years (Reiman et al, 2011) compared with 9\% in heterozygous carriers.

We report the occurrence of a mild form of A-T, with biallelic ATM mutations in a 44-year-old breast cancer patient (A-T213) who was investigated following a severe early and late reaction to radiotherapy.

\section{MATERIALS AND METHODS}

\section{Ethical approval}

Ethical Approval was given by the National Research Ethics Committee (REC Reference 07/H1210/155) and patient A-T213 gave informed consent. 


\section{Cell culture}

Epstein-Barr virus (EBV)-transformed lymphoblastoid cell lines (LCLs) were established from A-T patient and control lymphocytes. These LCLs were cultured in RPMI-1640 medium (Sigma-Aldrich, Irvine, UK) supplemented with $10 \%$ fetal calf serum (FCS; PAA Laboratories, Pasching, Austria). For transfected LCLs, $200 \mu \mathrm{g} \mathrm{ml}^{-1}$ of hygromycin B (Invitrogen, Paisley, UK) was added to the media.

\section{Colony-forming assays}

Serial dilutions of TERT-immortalised fibroblasts were irradiated with 1 to $5 \mathrm{~Gy}$ of $\gamma$-rays and seeded on to a lethally irradiated $(35 \mathrm{~Gy})$ feeder layer of normal fibroblasts $\left(6 \times 10^{4}\right.$ cells per $9.0 \mathrm{~cm}$ dish) in DMEM (Sigma-Aldrich) with $10 \%$ FCS. Cells were plated in quadruplicate and incubated in $5 \% \mathrm{CO}_{2}$ at $37{ }^{\circ} \mathrm{C}$ for $18-21$ days with medium changing. The medium was removed, colonies fixed with formaldehyde and stained with $0.5 \%$ Methylene Blue (Fisher Scientific, Loughborough, UK). The number of colonies on each plate was counted and percentage survival calculated.

\section{Modelling ATM mutations}

The ATM cDNA (mRNA RefSeq NM_000051.3) representing the complete open reading frame and coding sequence was cloned into plasmid pcDNA4/HisMax (Invitrogen) to create pcDNA4/HisMaxATM. This was used as a template in subsequent mutagenesis and cloning reactions. Site-directed mutagenesis was achieved using the Quikchange II site-directed mutagenesis kit (Stratagene, Amsterdam, The Netherlands). Both the $1 \mathrm{~A}>\mathrm{G}$ and the $8672 \mathrm{G}>\mathrm{A}$ ATM mutants were sequenced in full to verify the presence of the desired sequence change and absence of any unwanted mutation(s) acquired during the mutagenesis step. Full-length mutated $A T M$ constructs were transfected into ATM-null lymphoblastoid cells (Barone et al, 2009). For detailed methods, see Supplementary Information (Stewart et al, 2001).

\section{Immunoblotting for ATM expression and ATM kinase activity}

To analyse ATM activity, cells were either mock irradiated or exposed to $5 \mathrm{~Gy}$ ionising radiation and harvested after $30 \mathrm{~min}$, and nonirradiated cells were used for ATM expression analysis. Cell pellets were resuspended in UTB buffer $(9 \mathrm{M}$ urea, $50 \mathrm{~mm}$ Tris, $\mathrm{pH}$ $7.5,150 \mathrm{~mm} \beta$-mercaptoethanol) and lysed on ice by sonication. Lysate $(50 \mu \mathrm{g})$ was separated by SDS - polyacrylamide gel electrophoresis and the proteins transferred to nitrocellulose membrane (Pierce, Rockford, IL, USA). Nitrocellulose strips were subjected to immunoblotting and protein bands visualised using the enhanced chemiluminescence (ECL) system (Amersham, Little Chalfont, UK) and exposure to Hyperfilm MP autoradiography film (GE Healthcare, Little Chalfont, UK). Antibodies used for immunoblotting were ATM 11G12 (custom-made mouse monoclonal), pATM Ser1981 \#AF1655 (R\&D Systems, Abingdon, UK), Smc1 \#A300055A, pSmc1 Ser966 \#A300-050A, KAP-1 \#A300-275A, pKAP-1 Ser824 \#A300-767A (Bethyl Laboratories, Universal Biologicals, Cambridge, UK), Nbs1 \#Ab398, pNbs1 Ser343 \#Ab47272 (Abcam, Cambridge, UK), pP53 Ser15 \#9284, pChk2 Thr68 \#2661, CREB \#48H2 (Cell Signaling Technology, NEB, Hitchin, UK), pCREB Ser121 \#NB100-410 (Novus Biologicals, Cambridge, UK), $\gamma$-H2AX (Millipore, Watford, UK), H2A (Millipore), BRCA1 Ser1423 (Bethyl Laboratories), BRCA1 (Merck, Nottingham, UK) and Chk2 (gift from Dr G Stewart).

\section{In vitro ATM kinase assay}

Patient-derived LCLs were either mock irradiated or exposed to $5 \mathrm{~Gy}{ }^{137} \mathrm{Cs} \gamma$-rays and incubated for $30 \mathrm{~min}$ at $37^{\circ} \mathrm{C}$. Cells were harvested and lysed on ice for $30 \mathrm{~min}$ in TGN lysis buffer $(50 \mathrm{~mm}$ Tris, $\mathrm{pH} 7.5,150 \mathrm{~mm}$ sodium chloride, $10 \%$ glycerol, $50 \mathrm{~mm}$ $\beta$-glycerophosphate, $1 \%$ Tween- $20,0.2 \%$ nonidet $\mathrm{P} 40$ alternative, $1 \mathrm{~mm}$ dithiothreitol, $0.1 \mathrm{~mm}$ 4-(2-aminoethyl) benzenesulfonyl fluoride, $1 \mathrm{~mm}$ sodium orthovanadate, $10 \mathrm{~mm}$ sodium fluoride, $10 \mu \mathrm{g} \mathrm{ml}^{-1}$ aprotinin, $5 \mu \mathrm{g} \mathrm{ml}^{-1}$ leupeptin hydrochloride and $2 \mu \mathrm{g} \mathrm{ml}^{-1}$ pepstatin A). The ATM kinase was immunoprecipitated from $1 \mathrm{mg}$ of each whole-cell lysate using $10 \mu \mathrm{g}$ anti-ATM antiserum (Ab-3, Merck Chemicals, Darmstadt, Germany) for $2 \mathrm{~h}$ at $4{ }^{\circ} \mathrm{C}$. The ATM immunoprecipitates were pulled down using $30 \mu \mathrm{l}$ of Protein A agarose beads (Sigma-Aldrich) for $2 \mathrm{~h}$ at $4{ }^{\circ} \mathrm{C}$. Bead complexes were washed twice in TGN buffer, once in TGN buffer plus $0.5 \mathrm{M}$ lithium chloride and twice in ATM kinase buffer (20 mM HEPES, pH 7.5, $10 \mathrm{mM} \mathrm{MgCl}, 10 \mathrm{mM} \mathrm{MnCl}, 50 \mathrm{~mm} \beta$-glycerophosphate, $1 \mathrm{~mm}$ dithiothreitol, $0.1 \mathrm{~mm}$ sodium orthovanadate, $1 \mathrm{~mm}$ sodium fluoride, $0.1 \mathrm{M} 4$-(2-aminoethyl) benzenesulfonyl fluoride, $10 \mu \mathrm{g} \mathrm{ml}^{-1}$ aprotinin, $5 \mu \mathrm{g} \mathrm{ml}^{-1}$ leupeptin hydrochloride and $2 \mu \mathrm{g} \mathrm{ml}^{-1}$ pepstatin A) to remove residual detergent.

Each immunoprecipitate was resuspended in kinase buffer supplemented with $20 \mu \mathrm{m}$ ATP (Sigma-Aldrich), $5 \mu \mathrm{g}$ of purified GST-p53 $3_{1-72}$ substrate and $10 \mu \mathrm{Ci}{ }^{32} \mathrm{P}[\gamma-\mathrm{ATP}]$ (New England Nuclear, Boston MA, USA) and incubated at $30^{\circ} \mathrm{C}$ for $6 \mathrm{~min}$. Reactions were terminated by the addition of SDS sample buffer (250 mm Tris, pH 6.8, 8\% (w/v) sodium dodecylsulphate, 10\% (v/v) glycerol, $0.01 \%(\mathrm{w} / \mathrm{v})$ bromophenol blue, $400 \mathrm{~mm}$ dithiothreitol), incubated at $100^{\circ} \mathrm{C}$ for $5 \mathrm{~min}$ and proteins were fractionated on $6 \% / 8 \%$ biphasic SDS - polyacrylamide gels. The lower gel phase was dried at $80^{\circ} \mathrm{C}$ for $1 \mathrm{~h}$ and exposed to autoradiographic film to visualise phosphorylation of the GST-p53 $3_{1-72}$ substrate. The protein in the upper gel phase was transferred to nitrocellulose membrane (Pierce) and immunoblotted for the presence of immunoprecipitated ATM protein using anti-ATM antiserum (custom-made mouse monoclonal 11G12). Proteins were visualised as above.

\section{RESULTS}

\section{Clinical and neurological features}

Patient A-T213, a 44-year-old working mother, developed a lump in her right breast and was diagnosed with breast cancer (T2 G2, two nodes positive, ER-positive carcinoma of right breast). Treatment consisted of a lumpectomy followed by adjuvant chemotherapy (FEC) and radiotherapy (standard protocol delivering $40 \mathrm{~Gy}$ in fifteen fractions over 3 weeks). Post treatment, an acute radiation reaction at the severe end of the normal spectrum developed, followed by a late reaction manifest as shrinkage and deformation of the breast (Figure 1). The patient was investigated

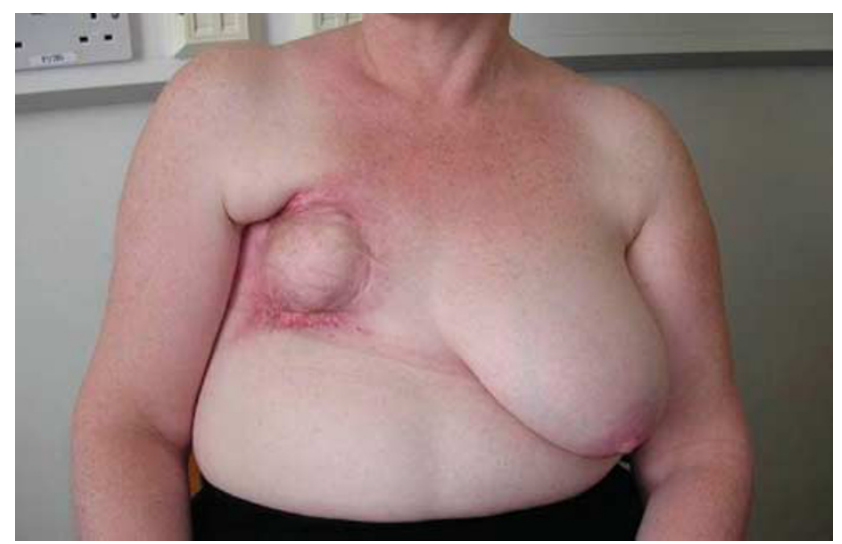

Figure I Appearance of right breast following radiotherapy. 
because of severe reaction to radiotherapy. Diagnostic testing of $B R C A 1$ and $B R C A 2$ genes by unidirectional DNA sequencing and MLPA did not detect any mutations.

Patient A-T213 walked into the clinic unaided and unsupported. There was no ataxia and tandem gait, feeding and swallowing were normal. There was no oculomotor apraxia, no hypometric saccades, no pursuit abnormalities and end gaze-evoked nystagmus but there was mild right esotropia. The patient showed no adventitious movements. Finger-nose coordination showed some end dysmetria and there was diminished vibration sense and joint position sense up to knees, confirmed by EMG (mild axonal polyneuropathy) and absent ankle and knee reflexes bilaterally.

\section{Cellular radiosensitivity}

Cultured skin fibroblasts from patient A-T213 showed increased radiosensitivity by colony-forming assay, but were not as sensitive as cells from a classical A-T patient (Figure 2). Similarly, examination of chromosomal radiosensitivity of blood from patient A-T213 showed a similar level of IR-induced damage that was $\sim 3 \times$ more than the control, but less than 'classical' A-T patients (A-T1 and A-T2, Table 1). Finally, following exposure to IR, the patient's fibroblasts showed a similar number of ATMdependent MDC1, $\gamma \mathrm{H} 2 \mathrm{AX}, 53 \mathrm{BP} 1$ and BRCA1 foci to the normal control, although they were noticeably less bright (Supplementary Figure 1). All these end points indicate some retained ATM function in cells from patient A-T213.

\section{ATM mutation analysis}

Two ATM mutations, c.8672G $>$ A. (p.Gly2891Asp) and c.1A $>$ G (Figure 3), were identified in the cells from patient A-T213 by DNA

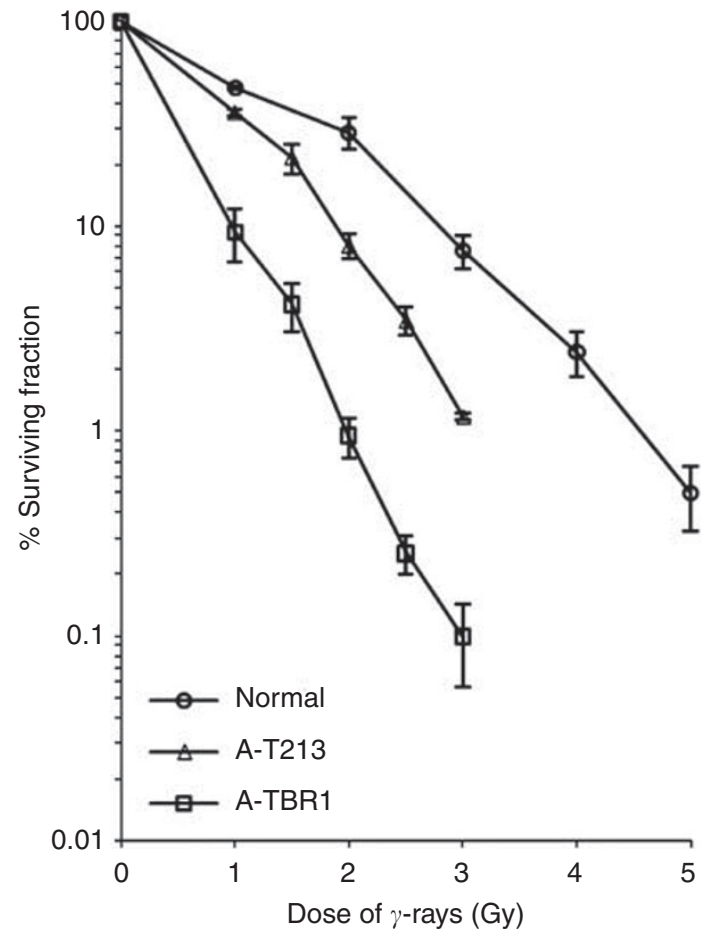

Figure 2 Colony-forming assay following exposure of cells to ${ }^{137} \mathrm{Cs}$ $\gamma$-rays. The proportion (\%) of surviving colonies was plotted against dose of $\gamma$-rays for normal TERT-immortalised cells, TERT-immortalised skin fibroblasts from patient A-T2I3 and TERT-immortalised fibroblasts from a classical A-T patient A-TIBR. The assay was repeated at least three times for each cell strain. Error bars show the s.e.m. survival at each dose. sequencing the exons and exon/intron boundaries of the ATM gene. Alterations were confirmed by sequencing cDNA derived from the LCLs of patient A-T213. Sequencing of the parental ATM genes confirmed that one mutation was carried on each allele of chromosome 11 , the c. $8672 \mathrm{G}>\mathrm{A}$ mutation was paternal and the c. $1 \mathrm{~A}>\mathrm{G}$ mutation maternal in origin.

The mutations are located in unusual positions, and both could theoretically result in expression of mutant ATM protein. The c. $1 \mathrm{~A}>\mathrm{G}$ affects the first base in the coding sequence and might be expected to ablate the initiation of ATM protein translation altogether. However, mutation of the initiation codon AUG to GUG could potentially result in the expression of ATM protein if the GUG in the RNA was able to allow translation. The c.8672G $>$ A (p.Gly2891Asp) is a missense mutation located in the first base of exon 60 (NM_000051.3) in the kinase domain. It was expected that at the cDNA level the c.8672G $>$ A mutation might result in loss of exon 60. However, this was not the case and, therefore, this mutation could also potentially result in the expression of mutant ATM protein. Expression of mutant ATM protein with some residual kinase activity from either one or both mutations could contribute to the milder clinical and cellular phenotype of patient A-T213.

\section{Cellular ATM protein expression and kinase activity}

The LCL of patient A-T213 expressed ATM protein, although the level was reduced compared with a normal LCL (Figure 4). Both A-T213 LCL (Figure 4A) and skin fibroblast lysates (Figure 4B and $\mathrm{C}$ ) showed residual ATM kinase activity. Therefore, both kinase assays in vivo confirmed the presence of ATM with kinase activity in the patient's cells. In order to estimate the level of ATM kinase activity, we performed an in vitro ATM kinase assay. The ATM protein immunoprecipitated from A-T213 LCL lysate showed greatly reduced activity towards a p53 substrate after DNA damage ( $\sim 12 \%$ of normal) (Figure $5 \mathrm{~A}$ and $\mathrm{B}$ ).

Finally, using LCL lysates we compared the ATM kinase activities of cells derived from patient A-T213 with cells from another breast cancer patient who was diagnosed with $\mathrm{A}-\mathrm{T}$ following a severe reaction to radiotherapy (A-T109, c.7271T $>$ G homozygous) (Stankovic et al, 1998). Although the level of ATM expression was highest in the c.7271T $>$ G cells, the level of kinase activity appeared to be slightly greater in cells from patient A-T213 (Supplementary Figure 2).

\section{Size and activity of the mutant ATM proteins}

Immunoprecipitation of ATM from an LCL derived from patient A-T86, carrying the initiating codon mutation, c.2T $>C$, on one allele and a null mutation on the second allele, revealed an ATM protein expressed at a lower level and slightly lower molecular weight (Figure 5, lanes 7 and 8) than ATM wt protein (Figure 5,

Table I Chromosome damage scored following exposure of a 72-h blood culture to I Gy ${ }^{137} \mathrm{Cs} \gamma$-rays $4 \mathrm{~h}$ before harvest

\begin{tabular}{lccccc}
\hline Patient & $\begin{array}{c}\text { No. of } \\
\text { mitoses } \\
\text { analysed }\end{array}$ & $\begin{array}{c}\text { No. of } \\
\text { tg }\end{array}$ & $\begin{array}{c}\text { No. of } \\
\text { tb }\end{array}$ & $\begin{array}{c}\text { No. of } \\
\text { trirad }\end{array}$ & $\begin{array}{c}\text { No. of } \\
\text { quad }\end{array}$ \\
\hline A-T213 sample 1 & 50 & 21 & 1 & 0 & 1 \\
A-T213 sample 2 & 50 & 25 & 4 & 0 & 0 \\
A-T1 & 50 & 118 & 38 & 5 & 4 \\
A-T2 & 50 & 74 & 20 & 1 & 2 \\
Control & 50 & 8 & 0 & 0 & 0 \\
\hline
\end{tabular}

Abbreviations: tg = chromatid gaps; tb = chromatid breaks; trirad = triradial chromosomes; quad=quadriradial chromosomes. A-TI and A-T2 are classical ataxia telangiectasia (A-T) patients. 
A

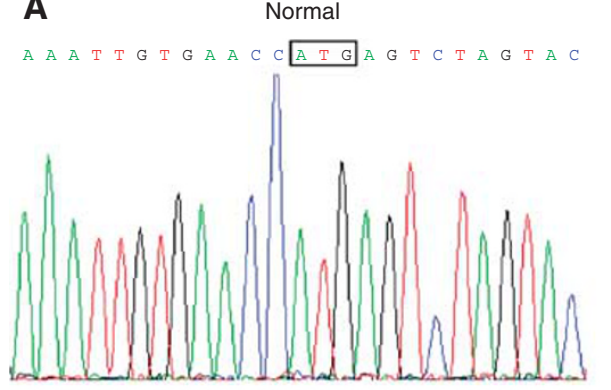

A-T $213 \quad 1 \mathrm{~A}>\mathrm{G}$

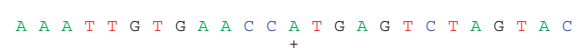

G

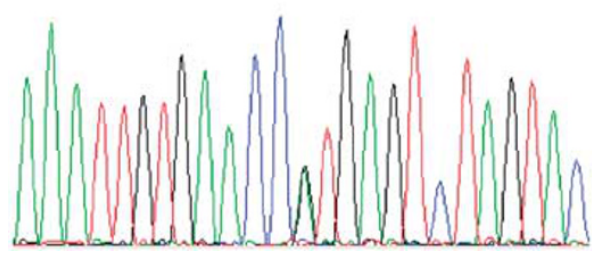

B
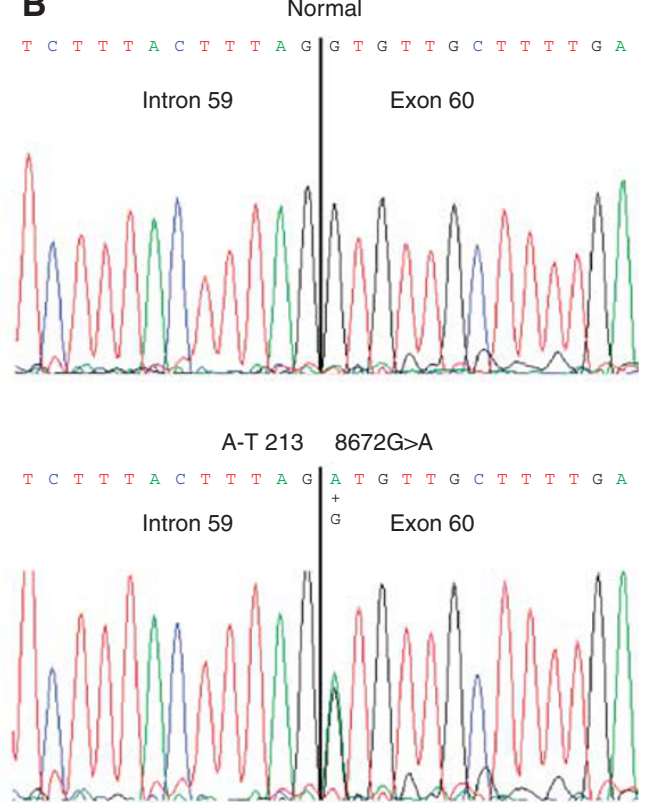

Figure 3 Electropherograms of mutations in genomic DNA in A-T2 I3. Top panels show the wt sequence from a normal individual and the lower panels the mutations at these positions in patient A-T2I3; (A) the c.IA>G mutation, and (B) the c.8672G $>$ A mutation. The boxed sequence triplet in (A) indicates the translation initiation codon.

A

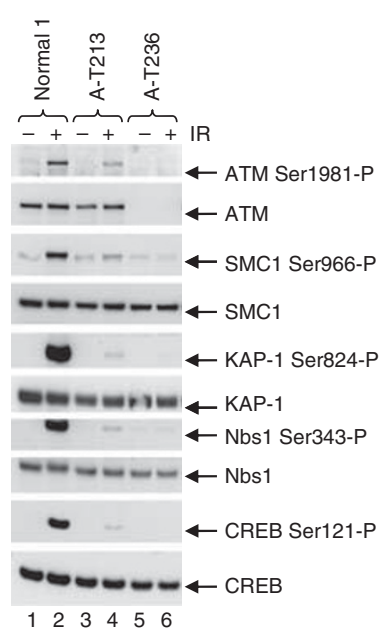

B

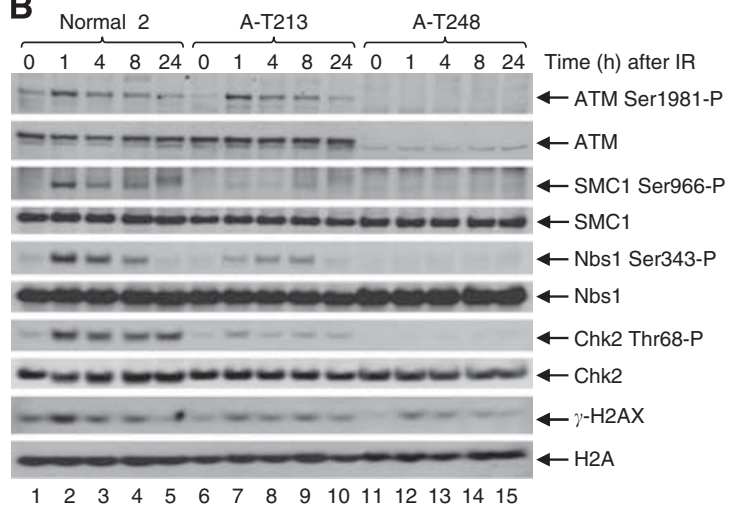

C

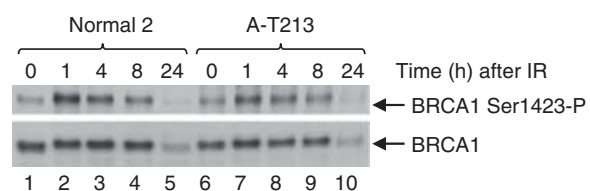

Figure 4 ATM from A-T2 I 3 LCL and fibroblast lysates shows some retained ATM kinase activity. (A) A-T2। 3 LCL lysate (lanes 3 and 4 ) shows the presence of some ATM kinase activity towards the ATM targets Smcl, KAPI, Nbs I and CREB after exposure to IR, but this is reduced compared with lysate from a normal LCL (lanes I and 2). LCL lysate from a classical A-T patient A-T236, which does not express ATM, is shown in lanes 5 and 6. (B and $\mathbf{C}$ ) Time course of phosphorylation of different ATM downstream targets by A-T2 I 3 fibroblast ATM protein, showing the presence of kinase activity at I h compared with the classical A-T patient (A-T248) but reduced activity compared with normal ATM (normal 2).

lanes 1 and 2). The slightly lower molecular weight ATM is consistent with initiation of translation from a downstream AUG codon resulting in a truncated protein. In translational terms the c. $1 \mathrm{~A}>\mathrm{G}$ mutation in A-T213 would be expected to behave like the c. $2 \mathrm{~T}>\mathrm{C}$ mutation as both mutations are in the initiation codon, and would be expected to compromise its function. This would result in the $\mathrm{clA}>\mathrm{G}$ mutation giving a similar truncated protein to the $\mathrm{c} 2 \mathrm{~T}>\mathrm{C}$ mutation.
The level of ATM protein immunoprecipitated from the LCL from patient A-T213 (Figure 5, lanes 5 and 6) was greater than that immunoprecipitated from cells from the c. $2 \mathrm{~T}>\mathrm{C}$ patient A-T86 (Figure 5, lanes 7 and 8) but less than from normal cells (Figure 5, lanes 1 and 2). Assuming that the c. $1 \mathrm{~A}>\mathrm{G}$ and c.2T $>\mathrm{C}$ mutant alleles result in a similar level of ATM, it is likely that most of the ATM protein in cells from patient A-T213 came from the c.8672G > A (p.Gly2891Asp) allele. Truncated ATM associated 


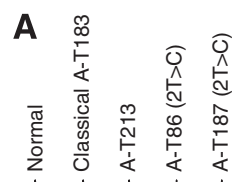

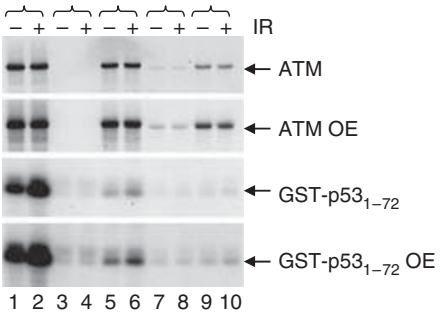

122345567889910

Figure 5 Full-length ATM is expressed in an LCL from patient A-T2I3, and immunoprecipitated ATM from this LCL has kinase activity in vitro. (A) Western blot (top and second panel; $O E=$ overexposed) showing expression of ATM in a normal LCL (lanes I and 2), absence of ATM in an LCL from a classical A-T patient (A-TI83, lanes 3 and 4) and reduced expression of ATM in LCL from A-T2I3 (lanes 5 and 6). Whereas the ATM in patient A-T2 3 appears to be full length, the ATM in an LCL from patient A-T86 with the c.2T>C mutation (and also null mutation c.7665delinsGTGA;p.His2555Gln ins*) is slightly truncated (lanes 7 and 8). It is likely that truncated ATM from c.2T $>\mathrm{C}$ in patient AT I 87 is obscured by the p.Arg3047X (c.9139C > T) mutant protein (lanes 9 and 10) and the truncated ATM from c.IA>G in patient A-T2I3 is obscured by the p.Gly289IAsp (c.8672G>A) mutant protein (lanes 5 and 6). Immunoprecipitated ATM was used to phosphorylate the $\mathrm{p} 53,-72$ substrate in vitro (third and fourth panel) following activation of ATM by IR. The level of normal radiation-induced ATM kinase activity is shown in lane 2. There is absence of induced activity in cells from classical A-T patient A-TI83 (lane 4) with no ATM protein. Lane 6 shows induced activity of ATM from the LCL of A-T2 13 but not from ATM of patient A-T86 with a $c .2 T>C$ mutation and a second truncating mutation (lane 8 ) or from patient A-TI87 with a c.2T >C mutation and c.9139C>T (p.Arg3047X). (B) Histogram of relative levels of ATM in vitro kinase activity from the immunoprecipitates in Figure 5A.

with the presence of the c. $1 \mathrm{~A}>\mathrm{G}$ mutation was not detected, probably because it was obscured by the full-length ATM from the c. $8672 \mathrm{G}>\mathrm{A}$ (p.Gly2891Asp) allele (Figure 5, compare lanes 5 and 6 and lanes 7 and 8). Consistent with this assertion was the finding that the ATM protein expressed from the c. $2 \mathrm{~T}>\mathrm{C}$ mutant allele in the LCL from patient A-T187 could not be discriminated from protein expressed from the second allele that was essentially fulllength p.Arg3047X (c.9139C > T) (Figure 5, lanes 9 and 10).

Interestingly, the level of ATM kinase activity in A-T213 was clearly greater than that of ATM immunoprecipitated from A-T cells carrying the mutation $c .2 \mathrm{~T}>\mathrm{C}$, which did not demonstrate any in vitro kinase activity (Figure $5 \mathrm{~A}$ and $\mathrm{B}$ ). This suggests that the ATM kinase activity in cells of patient A-T213 is from the c.8672G > A (p.Gly2891Asp) allele.

In order to determine whether one or both mutant alleles expressed ATM with some kinase activity, each mutation was modelled separately by site-directed mutagenesis of full-length normal ATM cDNA. Both the mutant protein associated with the c. $1 \mathrm{~A}>\mathrm{G}$ and the p.Gly2891Asp mutant protein are shown in Figure 6A. Interestingly, the $\mathrm{c} .1 \mathrm{~A}>\mathrm{G}$ protein was of lower molecular weight than wt ATM consistent with the use of a downstream methionine for initiation. In contrast to the level of ATM present in a normal LCL, the levels of both mutant proteins were low, although expression of the p.Gly2891Asp mutant protein was significantly higher than the c. $1 \mathrm{~A}>\mathrm{G}$ protein (Figure $6 \mathrm{~A}$, lanes 4 and 5). We were unable to measure the level of ATM kinase activity in either mutant protein because the levels of expression were too low. However, it was possible to analyse ATM kinase activity in the higher level of p.Gly2891Asp produced when it was expressed with N-terminal tags (Figure 6B). The p.Gly2891Asp
A

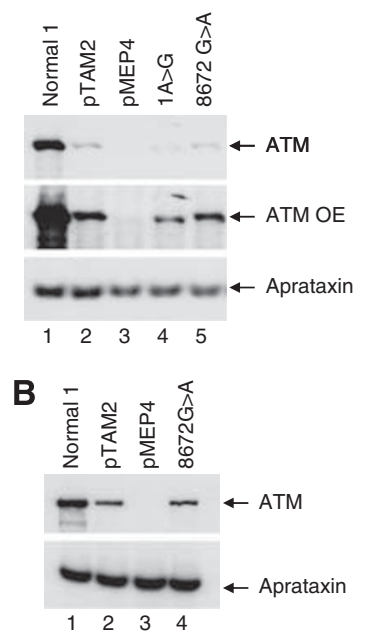

C

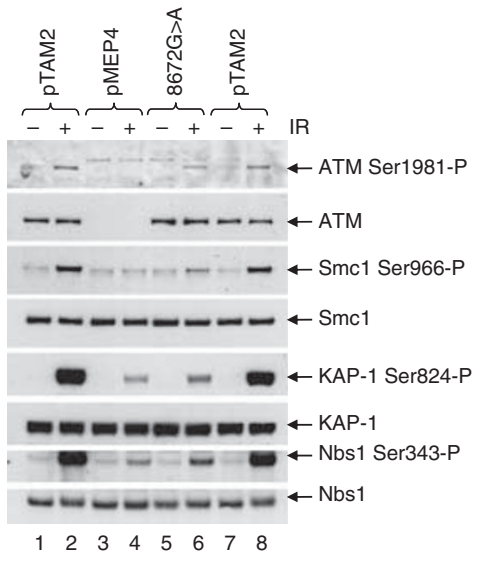

Figure 6 The p.Gly289|Asp protein has residual ATM kinase activity and a higher level of expression than the protein expressed from the c. $\mid A>G$ mutation. (A) ATM protein without tags. ATM protein expression after zinc induction in the $L C L$ stably transfected with PMEP4-ATM constructs was very low. Overexposure of the western blot showed that the $c . \mid A>G$ derived protein $(\mid A>G$, lane 4$)$ is truncated and accumulates to a lower level relative to the wt protein (pTAM2, lane 2) or the p.Gly289 IAsp protein $(8672 \mathrm{G}>\mathrm{A}$, lane 5 ). No ATM protein was expressed from the LCL transfected with vector alone (pMEP4, lane 3). Aprataxin was used as a loading control. (B) ATM protein with N-termina tags. The induced levels of both wt protein (PTAM2, lane 2) and p.Gly289|Asp protein (8672G >A, lane 4) were increased when the ATM constructs were $\mathrm{N}$-terminally tagged (compare with Supplementary Figure 2A). The p.Gly289IAsp (8672G >A) protein was expressed at a similar level to the wt protein. Aprataxin was used as a loading control. (C) Comparison of ATM kinase activity in lysates from LCLs stably transfected with pMEP4-ATM wt (pTAM2), PMEP4-ATM 8672G > A $(8672 \mathrm{G}>\mathrm{A})$ or pMEP4 vector alone (pMEP4) all with N-terminal tags. Expression of the p.Gly289|Asp (8672G >A) protein (lane 5) was comparable to that of wt ATM (pTAM2, lanes I and 7). The p.Gly289 |Asp (8672G > A) protein autophosphorylated Serl 98 I following IR (lane 6) to levels comparable to that of ATM wt protein (lanes 2 and 8). Levels of IR-induced phosphorylation of ATM targets Smcl, KAP-I and Nbs I by the p.Gly289 | Asp (8672G $>$ A) protein were substantially lower than those for the ATM wt protein (lanes 2 and 8 ) but higher than for vector alone.

mutant protein was autophosphorylated on ser1981 and was able to phosphorylate the ATM targets Smc1, KAP1, Nbs1 and CREB (Figure 6C, lane 6) after exposure to IR. The level of phosphorylation was greater than in cells with vector alone (Figure 6C, lane 4) but substantially lower than in cells with ATM wt (Figure 6C, lanes 2 and 8 ).

Therefore, of the two possible expressed mutant ATM proteins in A-T213, there was clear evidence that the p.Gly2891Asp mutant protein was active. Consequently, the ATM kinase activity in the cells of patient A-T213 was unlikely to be due to protein expressed from the c.1A $>\mathrm{G}$ mutation. Indeed, the mutant c.1A $>\mathrm{G} A T M$ cloned into pMEP4 was expressed as a lower molecular weight protein consistent with the kinase-inactive truncated protein expressed from the c.2T $>$ C ATM mutant.

\section{DISCUSSION}

At the time of breast cancer diagnosis and until the end of treatment, there was no clinical reason to suspect a diagnosis of $\mathrm{A}-\mathrm{T}$ in patient A-T213. Had it not been for the severe reaction to radiotherapy, it is possible that the disorder would have remained unrecognised as neurological features were minor. The A-T, therefore, was very mild. However, fresh lymphocytes, an LCL and 
fibroblasts from the patient all showed a clearcut increased radiosensitivity and defective focus formation of damage response proteins, although not to the same extent as cells from a classical A-T patient. In the context of this mild presentation, the two ATM mutations, c.8672G $>$ A (p.Gly2891Asp) and c.1A $>$ G, in patient A-T213 are both of considerable interest.

Interestingly, the c. $8672 \mathrm{G}>\mathrm{A}$ missense mutation was reported in one of the breast cancer cases (but not in the controls) in the study of Renwick et al (2006). Our study of this sequence change now confirms this as a true ATM mutation, allowing a low level of ATM expression with greatly reduced ATM kinase activity.

The ATM protein derived from the allele carrying the c. $1 \mathrm{~A}>\mathrm{G}$ mutation affecting the initiating methionine was truncated in the same way as a protein derived from another mutation $(\mathrm{c} .2 \mathrm{~T}>\mathrm{C})$ in the same codon. Cells from a patient with the c.2T $>C$ and an $A T M$-null mutation expressed a truncated ATM protein with no measurable ATM kinase activity. Therefore, it is unlikely that the c. $1 \mathrm{~A}>\mathrm{G}$ derived protein has any activity. In both cases, it is possible that translation of transcripts may initiate at the second or third in-frame AUG codons at codons 94 or 125, producing an N-terminally truncated ATM protein. The smaller molecular weight of ATM immunoprecipitated from both the c.2T $>C$ mutant cells and the modelled c. $1 \mathrm{~A}>\mathrm{G}$ is consistent with this.

An alternative hypothesis is that initiation occurs at a downstream out-of-frame AUG and that the truncated ATM protein expressed from the c. $1 \mathrm{~A}>\mathrm{G}$ and $\mathrm{c} .2 \mathrm{~T}>\mathrm{C}$ mutant alleles is the result of uncharacterised splicing events that restore the open reading frame. There are five out-of-frame AUGs between the primary AUG and the next in-frame AUG at codon 94 . However, none of them are in a good sequence context in comparison with the optimal Kozak sequence, suggesting that they are unlikely to function as translation-initiating codons. The most likely scenario, therefore, is that the translation complex scans the mRNA until it finds the in-frame AUGs at codons 94 or 125 .

A number of studies have reported ATM mutation carriers to have a 2-7-fold increased risk of breast cancer (Swift et al, 1991; Easton, 1994; Athma et al, 1996; Stankovic et al, 1998; Inskip et al, 1999; Janin et al, 1999; Geoffroy-Perez et al, 2001; Olsen et al, 2001; Bernstein et al, 2003; Thompson et al, 2005a, b; Reiman et al, 2011), with increased risk presumably associated with loss of heterozygosity, the sporadic loss of the normal ATM allele, resulting in either total loss of or a large reduction in functional ATM protein. Interestingly, this is the fourth time that neurologically milder A-T has been diagnosed following radiotherapy for breast cancer (Stankovic et al, 1998; Fang et al, 2010; Mandigers et al, 2011). Stankovic et al (1998) reported a woman who experienced a severe reaction of the breast and skin tissues after receiving adjuvant radiotherapy following resection of her breast cancer. This woman and two siblings, including a sister who also developed breast cancer, were homozygous for the ATM mutation c.7271T $>\mathrm{G}$ (p.Val2424Gly). The mutation was also identified in a second A-T family where breast cancer occurred in carriers of the mutation. The authors computed a relative risk of 12.7 associated with carrying this ATM mutation, compared with a relative risk of 74.1 in homozygotes, of developing breast cancer (Stankovic et al, 1998).
Two other cases have been described. In the first case, a 50-yearold breast cancer patient had a severe late adverse normal tissue reaction to radiotherapy (Fang et al, 2010). Nucleotide sequence analysis identified two nonallelic mutations in novel premature termination mutation (c.1918A $>\mathrm{T}$ (Lys640Stop)) and a (c.1066$6 \mathrm{~T}>\mathrm{G}$ (IVS10-6T-G)), which has previously been reported in A-T patients (Austen et al, 2008). Although not described as an A-T patient, this must be a strong possibility. In the second case, a 42 -year-old breast cancer patient showed extreme radiosensitivity in response to adjuvant radiotherapy following mastectomy (Mandigers et al, 2011). Only one ATM mutation (c.8147T $>\mathrm{C}$ (p.Val2716Ala)), which also has some ATM kinase activity (Verhagen et al, 2009), was identified and the patient subsequently diagnosed with A-T.

It is not known whether the ATM mutations in patient A-T213 were the cause of her breast cancer, although her relatively young age and the absence of mutations in her BRCA1 and BRCA2 genes would be consistent with this. With regard to potential mechanism involving ATM, the presence of two mutant ATM proteins, (p.Gly2891Asp and the c.1A $>\mathrm{G}$ derived protein) raises the possibility of a dominant-negative effect of the inactive protein on the active one. However, there is no evidence of a significant effect of the inactive c. $1 \mathrm{~A}>\mathrm{G}$ derived protein in reducing the activity of the more abundant active p.Gly2891Asp protein, using the levels of phosphorylation of ATM target proteins as a measure of this potential effect. Although the mechanism of breast cancer development is not known, it is possible that the overall level of ATM kinase activity is below the threshold for tumour protection and, indeed, any small dominant-negative effect of the inactive protein could contribute to this. An alternative mechanism for the development of breast cancer could be gain of function associated with a mutant ATM protein; this could also apply to both the p.Val2424Gly and the p.Val2716Ala ATM mutations.

The relationship between the clinical and cellular radiosensitivity in patient A-T213 is of some importance because despite not having the more extreme cellular radiosensitivity of a 'classical A-T patient', she clearly showed a severe clinical radiosensitivity. There are insufficient data to relate the severity of the clinical end point to that of the cellular end point, in terms of radiosensitivity. It is not possible to determine whether the residual activity of ATM protein expressed in her cells afforded her some degree of protection against the worst possible effect of the irradiation dose or, more generally, what is the threshold of cellular radiosensitivity that will result in a clinically severe reaction to IR.

\section{ACKNOWLEDGEMENTS}

We thank Cancer Research UK (C1016/A7395) for continued support and also the Ataxia Telangiectasia Society of the UK. We thank Penny Jeggo for the A-T TERT line AT1BR.

Supplementary Information accompanies the paper on British Journal of Cancer website (http://www.nature.com/bjc)

\section{REFERENCES}

Athma P, Rappaport R, Swift M (1996) Molecular genotyping shows that ataxia-telangiectasia heterozygotes are predisposed to breast cancer. Cancer Genet Cytogenet 92(2): 130-134

Austen B, Barone G, Reiman A, Byrd PJ, Baker C, Starczynski J, Nobbs MC, Murphy RP, Enright H, Chaila E, Quinn J, Stankovic T, Pratt G, Taylor AM (2008) Pathogenic ATM mutations occur rarely in a subset of multiple myeloma patients. Br J Haematol 142(6): 925-933
Barone G, Groom A, Reiman A, Srinivasan V, Byrd PJ, Taylor AM (2009) Modeling ATM mutant proteins from missense changes confirms retained kinase activity. Hum Mutat 30(8): 1222-1230

Bernstein JL, Bernstein L, Thompson WD, Lynch CF, Malone KE, Teitelbaum SL, Olsen JH, Anton-Culver $\mathrm{H}$, Boice JD, Rosenstein BS, Borresen-Dale AL, Gatti RA, Concannon P, Haile RW (2003) ATM variants 7271T $>G$ and IVS10-6T $>G$ among 
women with unilateral and bilateral breast cancer. Br J Cancer 89(8): $1513-1516$

Bernstein JL, Teraoka S, Southey MC, Jenkins MA, Andrulis IL, Knight JA, John EM, Lapinski R, Wolitzer AL, Whittemore AS, West D, Seminara D, Olson ER, Spurdle AB, Chenevix-Trench G, Giles GG, Hopper JL, Concannon P (2006) Population-based estimates of breast cancer risks associated with ATM gene variants c.7271T $>\mathrm{G}$ and c.1066-6T $>\mathrm{G}$ (IVS10-6T $>$ G) from the Breast Cancer Family Registry. Hum Mutat 27(11): 1122-1128

Carrillo F, Schneider SA, Taylor AM, Srinivasan V, Kapoor R, Bhatia KP (2009) Prominent oromandibular dystonia and pharyngeal telangiectasia in atypical ataxia telangiectasia. Cerebellum 8(1): 22-27

Easton DF (1994) Cancer risks in A-T heterozygotes. Int J Radiat Biol 66(6 Suppl): S177-S182

Fang Z, Kozlov S, McKay MJ, Woods R, Birrell G, Sprung CN, Murrell DF, Wangoo K, Teng L, Kearsley JH, Lavin MF, Graham PH, Clarke RA (2010) Low levels of ATM in breast cancer patients with clinical radiosensitivity. Genome Integr 1(1): 9

Geoffroy-Perez B, Janin N, Ossian K, Laug A, Croquette MF, Griscelli C, Debre M, Bressac-de-Paillerets B, Aurias A, Stoppa-Lyonnet D, Andrieu $\mathrm{N}$ (2001) Cancer risk in heterozygotes for ataxia-telangiectasia. Int $J$ Cancer 93(2): 288-293

Hiel JA, van Engelen BG, Weemaes CM, Broeks A, Verrips A, ter LH, Vingerhoets HM, van den Heuvel LP, Lammens M, Gabreels FJ, Last JI, Taylor AM (2006) Distal spinal muscular atrophy as a major feature in adult-onset ataxia telangiectasia. Neurology 67(2): 346-349

Inskip HM, Kinlen LJ, Taylor AM, Woods CG, Arlett CF (1999) Risk of breast cancer and other cancers in heterozygotes for ataxia-telangiectasia. Br J Cancer 79(7-8): 1304-1307

Janin N, Andrieu N, Ossian K, Lauge A, Croquette MF, Griscelli C, Debre M, Bressac-de-Paillerets B, Aurias A, Stoppa-Lyonnet D (1999) Breast cancer risk in ataxia telangiectasia (AT) heterozygotes: haplotype study in French AT families. Br J Cancer 80(7): 1042-1045

Lavin MF (2008) Ataxia-telangiectasia: from a rare disorder to a paradigm for cell signalling and cancer. Nat Rev Mol Cell Biol 9(10): 759-769

Mandigers CM, van de Warrenburg BP, Strobbe LJ, Kluijt I, Molenaar AH, Schinagl DA (2011) Ataxia telangiectasia: the consequences of a delayed diagnosis. Radiother Oncol 99(1): 97-98

McConville CM, Stankovic T, Byrd PJ, McGuire GM, Yao QY, Lennox GG, Taylor MR (1996) Mutations associated with variant phenotypes in ataxia-telangiectasia. Am J Hum Genet 59(2): 320-330

Olsen JH, Hahnemann JM, Borresen-Dale AL, Brondum-Nielsen K, Hammarstrom L, Kleinerman R, Kaariainen H, Lonnqvist T, Sankila R, Seersholm N, Tretli S, Yuen J, Boice Jr JD, Tucker M (2001) Cancer in patients with ataxia-telangiectasia and in their relatives in the Nordic countries. J Natl Cancer Inst 93(2): 121 - 127

Reiman A, Srinivasan V, Barone G, Last JI, Wooton LL, Davies G, Verhagen MM, Willemsen MA, Weemaes CM, Byrd PJ, Izatt L, Easton DF,
Thompson DJ, Taylor AMR (2011) Lymphoid tumours and breast cancer in ataxia telangiectasia; substantial protective effect of residual ATM kinase activity against childhood tumours. Br J Cancer 105(4): 586-591

Renwick A, Thompson D, Seal S, Kelly P, Chagtai T, Ahmed M, North B, Jayatilake H, Barfoot R, Spanova K, McGuffog L, Evans DG, Eccles D, Easton DF, Stratton MR, Rahman N (2006) ATM mutations that cause ataxia-telangiectasia are breast cancer susceptibility alleles. Nat Genet 38(8): 873-875

Shull ER, Lee Y, Nakane H, Stracker TH, Zhao J, Russell HR, Petrini JH, McKinnon PJ (2009) Differential DNA damage signaling accounts for distinct neural apoptotic responses in ATLD and NBS. Genes Dev 23(2): 171-180

Stankovic T, Kidd AM, Sutcliffe A, McGuire GM, Robinson P, Weber P, Bedenham T, Bradwell AR, Easton DF, Lennox GG, Haites $\mathrm{N}$ Byrd PJ, Taylor AM (1998) ATM mutations and phenotypes in ataxiatelangiectasia families in the British Isles: expression of mutant ATM and the risk of leukemia, lymphoma, and breast cancer. Am J Hum Genet 62(2): 334-345

Stewart GS, Last JI, Stankovic T, Haites N, Kidd AM, Byrd PJ, Taylor AM (2001) Residual ataxia telangiectasia mutated protein function in cells from ataxia telangiectasia patients, with 5762ins 137 and $7271 \mathrm{~T}->\mathrm{G}$ mutations, showing a less severe phenotype. J Biol Chem 276(32): 30133-30141

Sutton IJ, Last JI, Ritchie SJ, Harrington HJ, Byrd PJ, Taylor AM (2004) Adult-onset ataxia telangiectasia due to ATM 5762ins137 mutation homozygosity. Ann Neurol 55(6): 891-895

Swift M, Morrell D, Massey RB, Chase CL (1991) Incidence of cancer in 161 families affected by ataxia-telangiectasia. N Engl J Med 325(26): 1831-1836

Taylor AM, Byrd PJ (2005) Molecular pathology of ataxia telangiectasia. J Clin Pathol 58(10): 1009-1015

Thompson D, Antoniou AC, Jenkins M, Marsh A, Chen X, Wayne T, Tesoriero A, Milne R, Spurdle A, Thorstenson Y, Southey M, Giles GG, Khanna KK, Sambrook J, Oefner P, Goldgar D, Hopper JL, Easton D, Chenevix-Trench G (2005a) Two ATM variants and breast cancer risk. Hum Mutat 25(6): 594-595

Thompson D, Duedal S, Kirner J, McGuffog L, Last J, Reiman A, Byrd P, Taylor M, Easton DF (2005b) Cancer risks and mortality in heterozygous ATM mutation carriers. J Natl Cancer Inst 97(11): 813-822

Verhagen MM, Abdo WF, Willemsen MA, Hogervorst FB, Smeets DF, Hiel JA, Brunt ER, van Rijn MA, Majoor KD, Oldenburg RA, Broeks A, Last JI, van't Veer LJ, Tijssen MA, Dubois AM, Kremer HP, Weemaes CM, Taylor AM, van DM (2009) Clinical spectrum of ataxiatelangiectasia in adulthood. Neurology 73(6): 430-437

(c) (1) (2) This work is licensed under the Creative Commons (c) NG SA Attribution-NonCommercial-Share Alike 3.0 Unported License. To view a copy of this license, visit http://creativecommons. org/licenses/by-nc-sa/3.0/ 